体力科学（1999） 48，467 476

運動終了後の副交感神経活功の簡易評価法とコンディショニングにおける応用

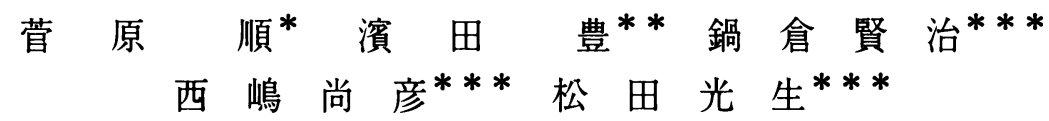

\title{
THE SIMPLIFIED EVALUATION OF POST-EXERCISE VAGAL REACTIVATION AND APPLICATION IN ATHLETIC CONDITIONING
}

\author{
Jun Sugawara, Yutaka Hamada, Yoshiharu Nabekura, Takahiko Nishijima and Mitsuo Matsuda
}

\begin{abstract}
It has been shown that the time constant of heart rate decline for the first $30 \mathrm{sec}\left(\mathrm{T}_{30}\right)$ after exercise, at an intensity lower than the ventilatory threshold (VT), can serve as a specific index to assess post-exercise vagal reactivation. The purpose of this study was to validate the use of a simpler alternative index, i. e. $\% \Delta \mathrm{HR}_{30}$ (the ratio of heart rate decrement for the first $30 \mathrm{sec}$ after exercise) for the evaluation of parasympathetic nervous reactivation, and to examine whether it would be a useful index in the conditioning of athletes. Eighteen college students performed 4 minutes cycle ergometer exercise routines at intensities of $40 \%, 80 \%$, and $120 \%$ VT to compare the $\% \Delta \mathrm{HR}_{30}$ and the $\mathrm{T}_{30}$. In addition, the $\% \Delta \mathrm{HR}_{30}$ was obtained by a field test ( 4 minutes jogging) in 15 college middle and long distance runners, every morning during summer camp training to assess the state of athletic conditioning. The $\% \Delta \mathrm{HR}_{30}$ at $80 \% \mathrm{VT}$ was similar to the value at $40 \% \mathrm{VT}$, but significantly different from the value at $120 \% \mathrm{VT}$, as was the $\mathrm{T}_{30}$ at $80 \% \mathrm{VT}$.

The \% $\Delta \mathrm{HR}_{30}$ significantly correlated with the $\mathrm{T}_{30}$ and $\mathrm{VO}_{2} \mathrm{max}$. During the camp, the \% $\Delta \mathrm{HR}_{30}$ was higher on mornings following light training days than on mornings following hard training days. These results suggest that the $\% \Delta \mathrm{HR}_{30}$, at an exercise intensity lower than the VT, could be a simple and useful index to evaluate post-exercise parasympathetic nervous reactivation in the conditioning of athletes.
\end{abstract}

(Jpn. J. Phys. Fitness Sports Med. 1999, $48: 467 \sim 476$ )

key words : heart rate, parasympathetic nervous system, athletic conditioning

\section{I . 粕}

心拍数は運動中に増大し, 運動終了とともに減 少する. 運動終了後にみられる心拍数の減少には, 運動中に抑制されていた副交感神経活動の再興奮 と賦活されていた交感神経活動の抑制が関与する とされている. 特に, 運動の終了後30秒間の心拍 数回復過程を自律神経遮断薬を用いて検討した Imai たち ${ }^{1)}$ の研究では, 換気性閥值 (VT) 以下の 強度の運動負荷後における心拍数減衰曲線を近似 した指数関数の時定数 $\left(\mathrm{T}_{30}\right)$ は, 主に運動終了後 の副交感神経再興奮過程を反映していることが示
唆されている.

運動トレーニングによる体力の向上に伴い, 安 静時の副交感神経活動が方進することが知られて いる.また, Imai たち ${ }^{1)}$ の研究では, アスリー トの $\mathrm{T}_{30}$ は一般健常者に比べ短縮していることが 示されている.他方, 過度に疲労しているアスリー トでは, 普段に比べて, 起床時心拍数が高い2), 最大下負荷運動後の心拍数の回復が遅い3), と いった徴候がみられることがある.これらのこと は, 副交感神経活動と体力水準や疲労との間には 密接な関連があることを示唆すると思われる。し たがって，運動終了後の副交感神経再興奮過程を

\footnotetext{
* 筑波大学体育科学研究科

$* *$ 筑波大学体育研究科

$* * *$ 筑波大学体育科学系

厂305-8574 茨城県つくば市天王台1-1-1
}

Doctoral program in Health and Sports Sciences, University of Tsukuba Master's program in Health and Physical Education, University of Tsukuba Institute of Health and Sports Sciences, University of Tsukuba 
数值化した $\mathrm{T}_{30}$ は, アスリートのコンディショ ニングにおける指標の一つとして利用できる可能 性がある。また， $\mathrm{T}_{30}$ はVT 以下の運動では運 動強度に関わらずほほ一定の値を示すとされてい $3^{1)}$. したがって, 厳密な運動負荷強度の設定が 難しい現場でも使用されうるとはいえ， $T_{30}$ を 現場で算出することは簡単ではないので，これに 代わる簡易評価法の開発が必要である。 そこで, 本研究では $\mathrm{T}_{30}$ に代わる副交感神経の再興奮過 程の指標として, 運動終了直後の30秒間における 心拍数滅少過程をほほ直線的であると仮定して, 30 秒間における心拍数隇少率 $\left(\% \Delta \mathrm{HR}_{30}\right)$ を提案す る.

本研究の目的は, アスリートのコンディショニ ングにおける\% $\% \mathrm{HR}_{30}$ の指標としての妥当性と 有用性を検討することである，本研究では，ま ず，\% $\Delta \mathrm{HR}_{30}$ は副交感神経の再興奮過程の指標 として $\mathrm{T}_{30}$ に代わりうるか否かを検討するため, VT 水準以下において強度の異なる定量運動負荷 を加え, 運動終了直後の心拍変動過程から $\mathrm{T}_{30}$ および $\% \Delta \mathrm{HR}_{30}$ を求めて両者を比較し, 同時に, 両者と体力水準の関連性についても検討した(研 究 1$)$. 次いで, \% $\mathrm{HR}_{30}$ がアスリートのトレー ニングに伴う疲労等の生体の反応を反映するか否 かを検討するため, 大学陸上部中長距離走選手の 夏季強化合宿において継続的にフィールドテスト を行い,トレーニング状況に伴う \% $\Delta \mathrm{HR}_{30}$ の変 動を観察した(研究 2 ).

\section{II. 方法}

\section{A. 対象}

研究 1 では健常な男子大学生18名 (年齢 : 24.2 \pm 2.2 歳, 身長 : $173.0 \pm 6.2 \mathrm{~cm}$, 体重 : $69.3 \pm 9.7$ $\mathrm{kg}$ )を対象とした。内訳は定期的な高強度の運動 トレーニングを行っている競技選手が 3 名, 中等 度の強度の運動を余层時間に週に $1 \sim 2$ 日程度 行っている者が10名, 運動習慣のない者が 5 名で あった. 研究 2 では大学生陸上中長距離走選手 15 名 (年齢：20.1 1.4 歳, 身長 : $168.1 \pm 5.8 \mathrm{~cm}$, 体重： $57.8 \pm 5.4 \mathrm{~kg}$ )を対象とした。それぞれの 実験に際して, 全ての被験者に実験内容や手順を
説明し，途中で辞退できることを理解させた上で 実験参加の同意を得た。

\section{B . 実験プロトコル}

研究 1 ：被験者全員に, $\mathrm{VO}_{2} \mathrm{max}$ および VT の測定を目的とした漸増負荷運動テストと，運動 終了後の副交感神経再興奮過程の評価を目的とし た定量負荷運動テストを，それぞれ異なる日に施 行した。定量負荷運動テストではVT が認めら れた時点の運動負荷量の $40 \%, 80 \%, 120 \%$ (それ ぞれ40\% VT, $80 \%$ VT, 120\% VT)を負荷した. それぞれの測定に先立ち，被験者には前日からの 激しい身体活動，飲酒，薬剂服用の禁止と充分な 睡眠の確保を指示した。当日は実験前 3 時間以内 の飲食を避けるよう指示した。

漸増負荷運動テストは自転車エルゴメーターを 用いて行った. 各被験者が10〜15分程度で疲労困 䣏に至るよう, 初期負荷量 $50 \mathrm{~W}$ から 1 分毎に 15

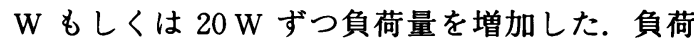
量漸増の割合は被験者の体重や運動歴を参考にし て決定した。運動中の換気動態を呼気ガス分析器 (ミナト医科学社製，AE-280)を用い breath-bybreath で連続測定し, 酸素摄取量, 二酸素炭素 排出量, 分時換気量の 30 秒間毎の平均値を算出し た. $\mathrm{VO}_{2} \max$ は疲労困䣏で運動継続が不可能と なった時点の酸素摄取量とした.VTは得られ た酸素捸取量と二酸化炭素排出量から V-Slope 法 ${ }^{4)}$ により推定した.

定量負荷運動テストは，漸増負荷運動テスト施 行後 2 週間以内に行った. 被験者は自転車エルゴ メータ上で 2 分間の安静をとった後, 予備運動 (40\% VT) 1 分間と 3 種類の強度の異なる主運動 (40\% VT, $80 \% \mathrm{VT}, 120 \% \mathrm{VT}) 3$ 分間ずつをそ れぞれ組み合わせた計 4 分間の運動を, $40 \% \mathrm{VT}$, $80 \%$ VT，および $120 \%$ VT 強度の順に，6 分間 の安静を挟んで行った(図 1). 各テスト間および $120 \% \mathrm{VT}$ 強度での運動終了後は, 自転車エルゴ メータ上で安静を保った，収縮期血圧および拡張 期血圧は，上腕にカフを巻き自動血圧計(コーリ ン社製，STBP-780B）を用いて，運動直前と主運 動時の最後の 1 分間に測定した，運動開始 2 分前 


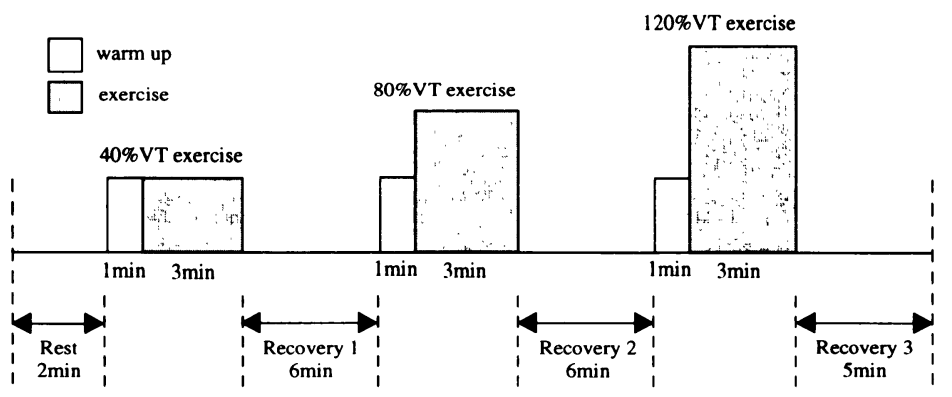

Fig. 1. Protocol of exercise test.

(安静時)から $120 \%$ VT 運動終了 5 分後までの換 気動態と心電図 $\mathrm{R}-\mathrm{R}$ 間隔データを記録した。運 動中の換気動態は漸増負荷運動テストと同様の方 法で測定し, 安静中および各主運動の最後の30秒 間の酸素消費量を求めた，心電図 $R-R$ 間隔デー 夕は, 瞬時心拍数記録器 (ナデックス社製, A M01-M01）を用い，胸部双極誘導法により1 $\mathrm{msec}$ の時間分解能で記録した。記録した R-R 間 隔データは,パーソナルコンピュータ（NEC 社製， PC9801)に取り込み，解析プログラム(ナデック ス社製，AM01-F01A）を用いて瞬時心拍数に換 算した。得られた瞬時心拍数データから，各負荷 強度における主運動の最後の 1 分間の平均心拍数 を求めて運動時心拍数とした。 また，運動終了後 の瞬時心拍数デー夕を副交感神経再興奮過程の解 析に用いた。

研究 2 : 大学陸上競技部中長距離走選手の夏季 強化合宿 (平成10年 7 月13日～31日) において, 2 日目以降早朝のトレーニング開始前にフィールド テストを行い, 運動終了後の副交感神経再興奮過 程の評価を行った。フィールドテストは 4 分間の ランニング負荷により行った． 2 分間の立位安静 をとった後， 4 分間のジョギングを行い，4 分経 過した時点で立ち止まり，その場で1分間の立位 安静を保った。ジョギングペースは普段のトレー ニングで VT 以下の走トレーニングとして行わ れているペースとし,多少の個人差はあるものの, 4 分間でおよそ $800 \mathrm{~m}$ が目安となっていた. テ スト中の心拍数を無線式心拍数記録器 (Polar 社 製，バンデージ XL)にて連続的に記録し，5秒
間毎の平均値を求めた。 また，トレーニング量の 評価として，毎日の走行距離を対象者自身に記録 させた。

合宿はほほ 3 週間にわたって行われた。初日は 合宿地への移動日であり, 午後にのみ軽度のト レーニングが行われた，2 日目以降は基本的に， 早朝 (軽度のトレーニング) と午後 (高強度トレー ニング)の 1 日 2 回トレーニングを行う日が 2 日 続き，次いで早朝のみに軽度のトレーニングを行 う積極的休養を主体とした日が1日という，3 日 周期のトレーニングスケジュールとなっていた. ただし，第 3 番目の周期のあとに，早朝と午後に トレーニングを行う日と早朝のみにトレーニング を行う日が 1 日ずつの， 2 日周期の変則的なスケ ジュールが用意された $(11 ， 12$ 日目)。この時期に トレーニング量を落とし，前期の疲労を解消させ ることが意図されていたためである.

\section{C . 運動終了後の副交感神経再興公過程の評価}

$\mathrm{T}_{30}$ ： $\mathrm{T}_{30}$ の算出は Imai たち ${ }^{1)}$ の方法に従っ た. 運動終了後30秒間の瞬時心拍数デー夕を対数 変換して一次回帰直線を求め, 得られた直線の勾 配の逆数を $\mathrm{T}_{30}$ とした.

$\% \Delta \mathrm{HR}_{30}$ : 定量運動負荷テストでは，運動終了 直前 5 秒間の平均心拍数と運動終了後 25 秒目から 30秒目までの平均心拍数をそれぞれ求め，再者の 差を運動終了直前 5 秒間の平均心拍数で除し, $\% \Delta \mathrm{HR}_{30}$ とした. フィールドテストでは，テス ト中に記録した心拍数の経時データより，運動終 了時点および運動終了後 30 秒経過時点の心拍数を 
それぞれ求め, 両者の差を運動終了時点の心拍数 で除し，\% $\mathrm{HR}_{30}$ とした。

\section{D. 分析方法}

研究 1：40\% VT, $80 \%$ VT, $120 \%$ VT 強度の 運動間で, $\mathrm{T}_{30}, \% \Delta \mathrm{HR}_{30}$, 運動時心拍数, 収縮 期血圧, 拡張期血圧,および酸素消費量を比較し, 運動負荷強度依存性を検討した。次いで, $\mathrm{T}_{30}$ と\% $\mathrm{HR}_{30}$ との相関関係，さらに， $\mathrm{T}_{30}$ および $\% \Delta \mathrm{HR}_{30}$ と $\mathrm{VO}_{2} \max$ との相関関係を検討した.

研究 2 : トレーニングでの走行距離, 早朝のト レーニンク前に行ったフィールドテストでの運動 終了時の心拍数および \% $\Delta \mathrm{HR}_{30}$ について, 被験 者全員の平均値を毎日求め, 合宿を通じての変動 を観察した．前日に，早朝と午後の 2 回トレーニ ングが行われた日と早朝のみにトレーニングが行 われた日とで \% $\Delta \mathrm{HR}_{30}$ の平均値を比較した. 同 様に, 合宿の前半の $3 \sim 8$ 日目と後半の14 19日 目とで，前日の走行距離，\% $\mathrm{HHR}_{30}$ ，それぞれの 平均值を比較した. 比較の対象とした期間 (3〜 8 日目および14〜19日目)は，3 日周期のトレー ニングスケジュールのはじめの 2 周期 $(2 \sim 7$ 日 目) と最後の 2 周期 (13 18日目)のそれぞれ翌日 とした.

\section{E. 統計学的解析}

各データは平均値士標準偏差で示した. 研究 1 においては，相関関係の検討に単相関分析を行っ た. 運動負荷強度依存性の検討には運動負荷強度 を要因とする一元配置分散分析を用い, 有意差が 認められた場合に, フィッシャーの PLSD 法に
より多重比較検定を行った. 研究 2 における平均 值の比較には, ランダマイゼーション検定 ${ }^{5,6)}$ 用いた。本研究のように, デー夕間にトレーニン グ状況に伴う系列依存性が存在する場合は, 無作 為配置により群を確率的な意味で等質化すること が必要なためである。

有意水準は $5 \%$ とした。

\section{III. 桔}

\section{果}

研究 1 : 被験者の $\mathrm{VO}_{2} \mathrm{max}$ および $\mathrm{VT}$ 時の酸 素摄取量の平均值はそれぞれ $46.9 \pm 9.7$ $\mathrm{ml} / \mathrm{kg} / \mathrm{min}, 29.9 \pm 4.8 \mathrm{ml} / \mathrm{kg} / \mathrm{min}$ であった. 各 指標の運動負荷強度毎の比較を表 1 に示した。運 動時心拍数, 収縮時血圧, 酸素消費量は, 負荷強 度が高いほど高値を示し，各負荷強度間に有意差 が認められた。 $\mathrm{T}_{30}$ は $40 \% \mathrm{VT}$ および $80 \% \mathrm{VT}$ 強度でほほ同じ值を示し, $120 \% \mathrm{VT}$ 強度では 40\% VTおよび $80 \%$ VT 強度に比して有意に高 値を示した。 \% $\mathrm{HR}_{30}$ は，40\% VT および $80 \%$ VT 強度ではほほ同じ值を示し，120\% VT 強度 では $40 \%$ VT および $80 \%$ VT 強度に比して有意 に低值を示した，拡張期血圧は，各運動負荷強度 間で有意差は認められなかった。図 2 に $40 \%$ お び $80 \% \mathrm{VT}$ 強度での \% $\Delta \mathrm{HR}_{30}$ を比較して示す. $40 \%$ および $80 \% \mathrm{VT}$ 強度における \% $\Delta \mathrm{HR}_{30}$ は, ほほ同一の值をとることが示された８0\% VT 強度における $\mathrm{T}_{30}$ と\% $\mathrm{HHR}_{30}$ との間には, 極め て強い有意の相関関係が認められた $(\mathrm{r}=-0.954$, $\mathrm{P}<0.0001$; 図 3-A). $40 \% \mathrm{VT}$ 強度における $\mathrm{T}_{30}$ と $\% \Delta \mathrm{HR}_{30}$ との間にも, 有意の相関関係が 認められた $(\mathrm{r}=-0.727, \mathrm{P}<0.001 ;$ 図 $3-\mathrm{B})$.

Table 1. Physiological responses to exercise.

\begin{tabular}{lcrrr}
\hline & $40 \% \mathrm{VT}$ & \multicolumn{2}{c}{$80 \% \mathrm{VT}$} & \multicolumn{1}{c}{$120 \% \mathrm{VT}$} \\
\hline $\mathrm{HR}(\mathrm{bpm})$ & $97.1 \pm 8.2^{*}$ & $126.8 \pm 8.7$ & $159.9 \pm 10.6^{*}$ \\
$\mathrm{~T}_{30}(\mathrm{sec})$ & $97.9 \pm 36.8$ & $106.6 \pm 40.1$ & $201.2 \pm 87.2^{*}$ \\
$\% \Delta \mathrm{HR}_{30}(\%)$ & $27.0 \pm 7.1$ & $26.9 \pm 9.2$ & $16.1 \pm 7.3^{*}$ \\
$\mathrm{SBP}(\mathrm{mmHg})$ & $153.2 \pm 12.2^{*}$ & $186.9 \pm 15.9$ & $218.9 \pm 22.6^{*}$ \\
$\mathrm{DBP}(\mathrm{mmHg})$ & $78.6 \pm 9.3$ & $75.7 \pm 12.5$ & $73.1 \pm 16.4$ \\
$\mathrm{VO}_{2}(\mathrm{ml} / \mathrm{min})$ & $992 \pm 189^{*}$ & $1668 \pm 320$ & $2331 \pm 434 *$ \\
\hline
\end{tabular}

Data are expressed as mean $\pm \mathrm{SD} .^{*}: \mathrm{P}<0.05$ vs $80 \% \mathrm{VT}$. 


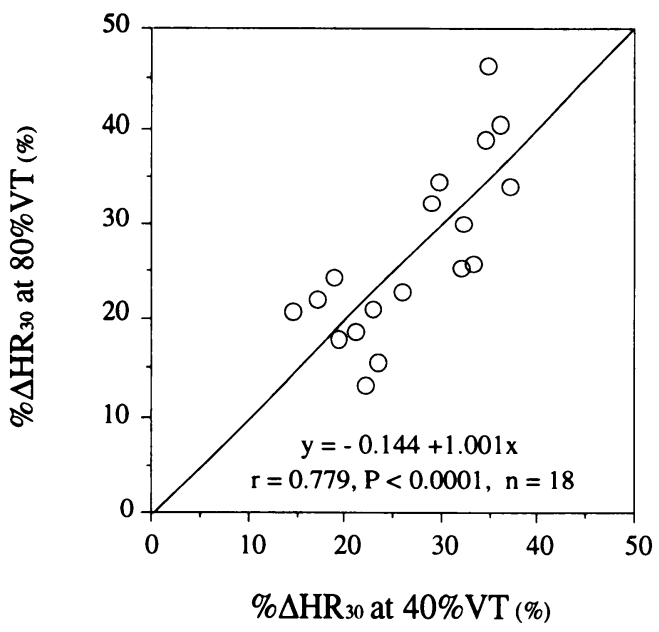

Fig. 2. Relationship between $\% \Delta \mathrm{HR}_{30}$ at $40 \%$ VT and $80 \%$ VT.

$\mathrm{VO}_{2} \mathrm{max}$ と $80 \% \mathrm{VT}$ 強度における $\mathrm{T}_{30}(\mathrm{r}=$ $0.505, \mathrm{P}<0.05 ;$ 図 $4-\mathrm{A})$ および $\% \Delta \mathrm{HR}_{30}(\mathrm{r}=$ $0.576, \mathrm{P}<0.05$; 図 $4-\mathrm{B})$ との間に，有意の相 関関係が認められた.

研究 $2 ：$ 図 5 に合宿中の走行距離とフィール ドテストにおける運動終了時の心拍数および $\% \Delta \mathrm{HR}_{30}$ を示した，運動終了時の心拍数は概ね 120〜130 bpm に保たれており，フィールドテス トはVT水準以下の運動負荷で行われていたと いえる. 前日が, 早朝と午後の 2 回トレーニング が行われトレーニング量が多かった日 (H-TR : 走行距離 $36.8 \pm 4.2 \mathrm{~km})$ と積極的休養が主体の卜 レーニング量が少なかった日（L-TR：17.5 4.1 $\mathrm{km})$ とで \% $\Delta \mathrm{HR}_{30}$ の平均值を比較すると，\% $\mathrm{HR}_{30}$ は L-TR で有意に高值を示した $(\mathrm{H}-\mathrm{TR}$ ： $25.2 \pm 1.6 \%, \quad \mathrm{~L}-\mathrm{TR}: 28.2 \pm 1.5 \%, \mathrm{P}<0.01$ : 図 6$)$. 合宿前半の $3 \sim 8$ 日目と後半の14 19日 目との比較では, 前日の走行距離平均値 $(3 \sim 8$ 日目: $31.7 \pm 8.3 \mathrm{~km}, 14 \sim 19$ 日目: $29.3 \pm 12.7$ $\mathrm{km}), \% \Delta \mathrm{HR}_{30}$ 平均値 ( $3 \sim 8$ 日目: $26.3 \pm 2.0 \%$, 14〜19日目：25.6土2.9\%；図 7 ), ともに有意差 は認められなかった。

なお，合宿期間中に特に強い疲労感を訴えた者 や，オーバートレーニング症候群のような病的疲 労状態を示す者はいなかった。
(A)

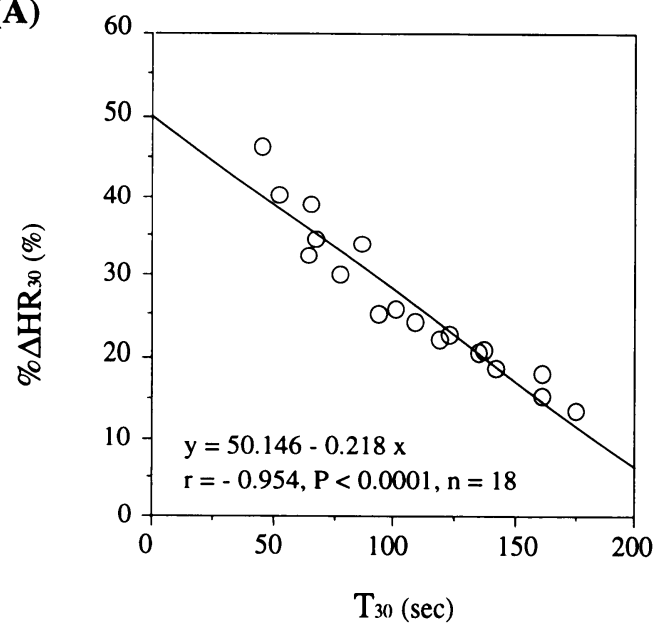

(B)

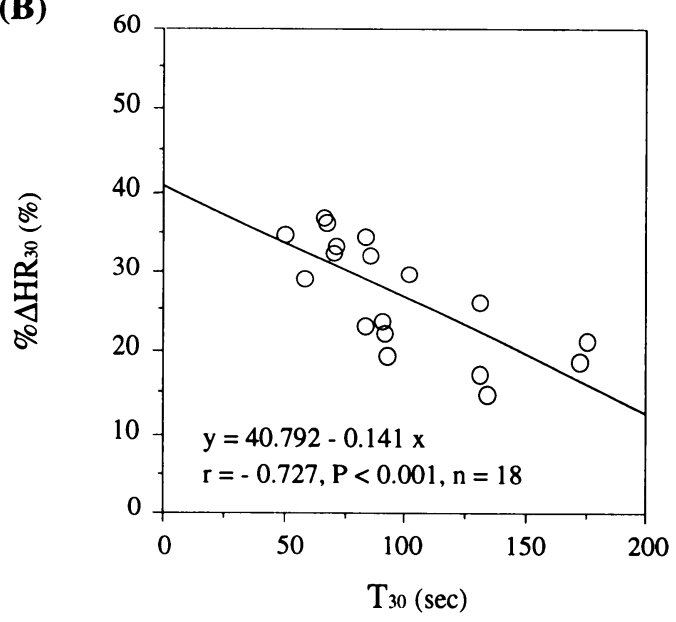

Fig. 3 Relationships between $\mathrm{T}_{30}$ and $\% \Delta \mathrm{HR}_{30}$ (A : $80 \%$ VT, B : $40 \%$ VT).

\section{N. 考}

察

本研究では，まず，運動の終了後30秒間の心拍 数回復過程を直線で近似して得られる心拍数減少 率 $\left(\% \Delta \mathrm{HR}_{30}\right)$ が運動終了後における副交感神経の 再興奮過程の指標として妥当であるかを検討する ため, 30 秒間の心拍数回復過程を指数関数で近似 して得られる時定数 $\left(\mathrm{T}_{30}\right)$ と比較した. $\mathrm{T}_{30}$ およ び \% $\Delta \mathrm{HR}_{30}$ は, VT 以下 $(40 \%$ および $80 \% \mathrm{VT})$ の運動負荷では，ほほ等しい値を示し，また， $\mathrm{T}_{30}$ と $\% \Delta \mathrm{HR}_{30}$ との間には強い相関関係が認め 
(A)

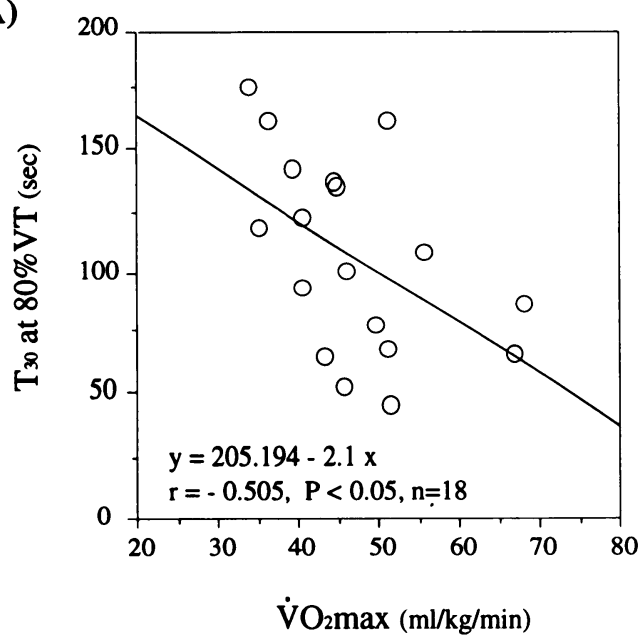

(B)

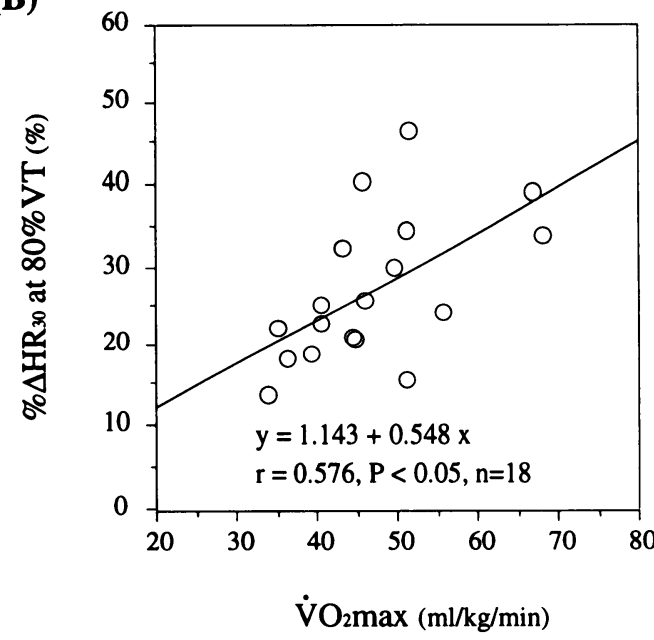

Fig. 4. Relationships between $\mathrm{VO}_{2} \max$ and $\mathrm{T}_{30}$ at $80 \% \mathrm{VT}(\mathrm{A})$, and between $\mathrm{VO}_{2} \max$ and $\% \Delta \mathrm{HR}_{30}$ at $80 \%$ VT (B) .

られた。ささらに, $\mathrm{T}_{30}$ および $\% \Delta \mathrm{HR}_{30}$ は $\mathrm{VO}_{2} \max$ と有意に相関した。すすおち，\% $\% \mathrm{HR}_{30}$ は副交 感神経の再興奮過程の指標である $\mathrm{T}_{30}$ に代わり うる指標であることが確かめられ，また，体力水 準 $\left(\mathrm{VO}_{2} \max \right)$ と有意に関連する指標であることも 示された． \% $\Delta \mathrm{HR}_{30}$ は測定が簡便にできること に加え，VT 以下の運動であれば負荷強度に影 響されないので，負荷強度の正確な設定が困難な フィールドにおいて有用な指標であると考えられ た. 次いで, 大学陸上部中長距離走選手の夏季強
化合宿において，毎朝のトレーニング開始前に フィールドテストにより測定した $\% \Delta \mathrm{HR}_{30}$ をト レーニング状況と対応させて検討したところ，\% $\Delta \mathrm{HR}_{30}$ は前日のトレーニング量に応じて変動し, トレーニング量が多かった日の翌朝には低値を, 積極的休養を主体にした日の翌朝には高値を示し た。すなわち，\% $\Delta \mathrm{HR}_{30}$ は疲労ないし疲労の回 復状況と連動して変化する可能性が示唆された。

Imai たち ${ }^{1)}$ は， $T_{30}$ が副交感神経遮断薬を投 与すると延長するが, 交感神経遮断薬を投与して も変化しないことから，運動終了直後における心 拍数の隇衰は主に副交感神経の再興奮により生じ るとしている。また， $\mathrm{T}_{30}$ は運動強度に大きく 影響されないこと，あるいは運動終了時の血圧や 酸素消費量にも影響されないことから，運動終了 直後の副交感神経の再興奮には, 動脈圧受容体や 活動筋の機械的あるいは化学的受容器を介する反 射よりも，運動野から副交感神経中枢への抑制指 令等の中枢性機構が関与している可能性が大きい としている ${ }^{1)}$ 。つまり，運動中は運動野から副交 感神経中枢への抑制性の指令が働いているが，運 動終了直後にはそれがなくなるために，副交感神 経活動が回復し，その結果，心拍数が減少すると 考えられる。ただし，VT 水準と 50\% VT 水準 における運動後の $\mathrm{T}_{30}$ には有意な差は認められ なかったが，最大運動後にはVT 水準の運動後 に比べてわずかではあるが有意に延長したので， 高強度の運動では末梢からの反射や血中のカテコ ラミンが，中枢指令に基づく副交感神経の再興奮 を抑制する可能性があると推測されている1). 本 研究でも，40\%VTと $80 \% \mathrm{VT}$ 水準における $\mathrm{T}_{30}$ の值には有意差が認められず，120\% VT 水 準の運動後にのみ有意に高値を示した．いずれに せよ，VT 水準以下の運動負荷では $\mathrm{T}_{30}$ はほほ 一定の值を示すと考えられ，運動負荷強度を厳密 に設定することが困難なフィールドにおいて，副 交感神経の再興奮過程を反映する指標として有用 であろうと思われる.

$\mathrm{T}_{30}$ が運動強度に大きな影響を受けないこと は，指標としての有用性を示すものであるが, フィールドにおいて心拍数の減衰過程を一次指数 


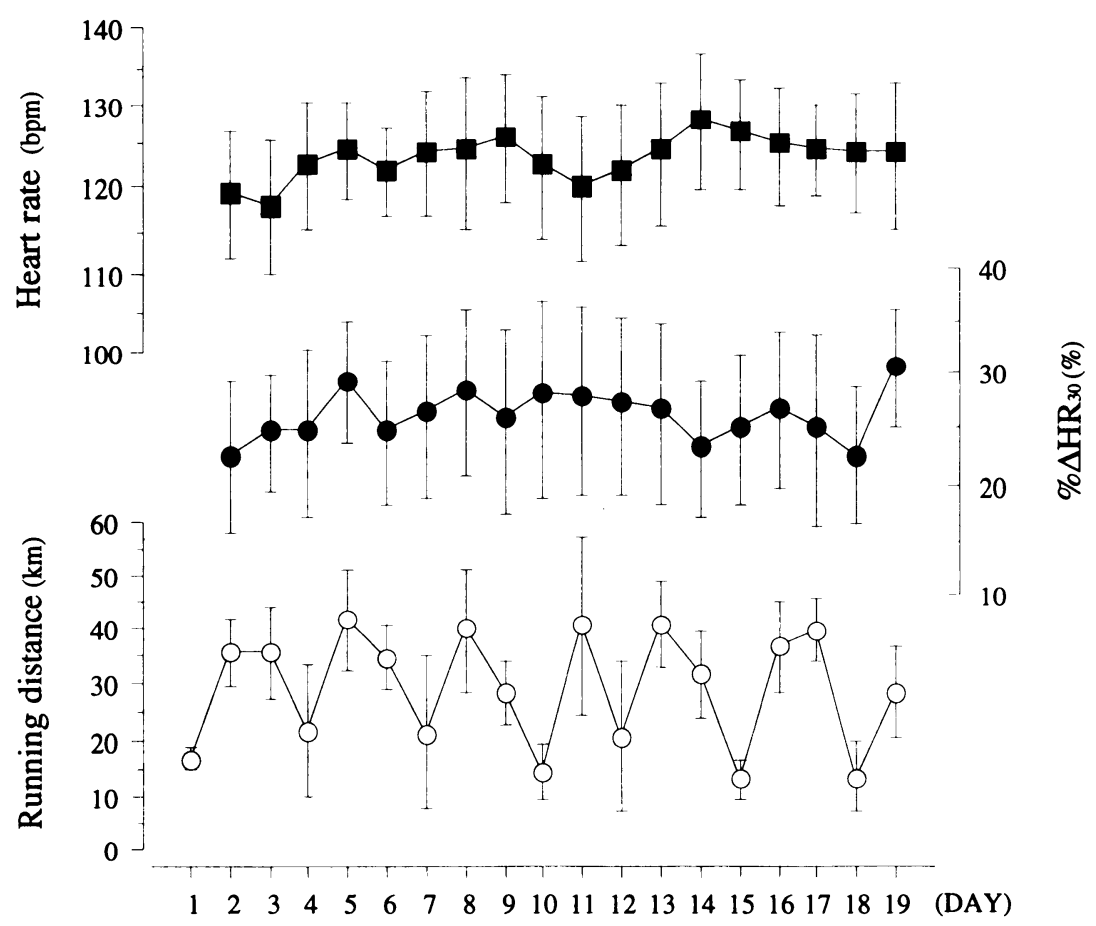

Fig. 5. The daily change in heart rate at the end of jogging $(\boldsymbol{\square}), \% \Delta \mathrm{HR}_{30}(\mathbf{O})$, and running distance $(O)$ during summer camp. Data are expressed as mean \pm SD.

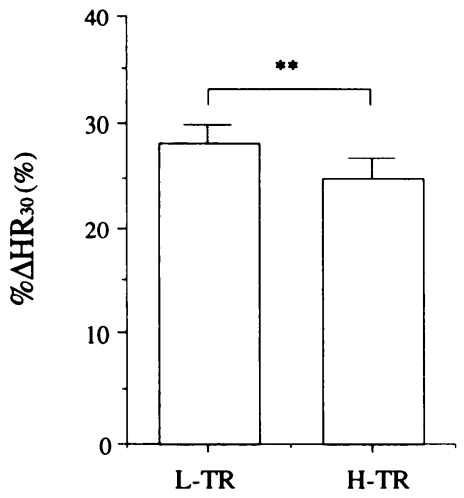

Fig. 6. $\% \Delta \mathrm{HR}_{30}$ in morning following light training day (L-TR) and morning following hard training day $(\mathrm{H}-\mathrm{TR})$. Data are expressed as mean $\pm \mathrm{SD} .^{* *}: \mathrm{P}<0.01$.

曲線に当てはめて時定数を求めることは実際には 困難である，そこで，本研究では，それに代わり うる簡便な指標として30秒間の減衰過程を直線で 近似し，\% $\% \mathrm{HR}_{30}$ を求めて $\mathrm{T}_{30}$ と比較した。 た

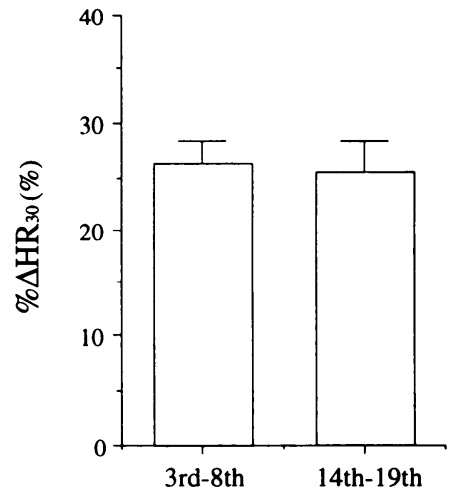

Fig. 7. $\% \Delta \mathrm{HR}_{30}$ for the $3 \mathrm{rd} \sim 8$ th day and $14 \mathrm{th} \sim$ 19 th day. Data are expressed as mean \pm SD.

だし，直線で近似するとしても，心拍数の直線回 㷌式から勾配を求める方法では, $\mathrm{T}_{30}$ を求める 手法と比べて簡便とはいえないので, 本研究では, 運動終了直前と運動終了 $25 \sim 30$ 秒後の各 5 秒間の 平均心拍数から心拍数減少率を求めることにし た. Imai たち1)によれば，運動終了後の20秒間 
における心拍数減衰曲線の時定数と 30 秒間におけ る時定数とは有意な差を示さなかったので，25〜 30秒間の平均心拍数で代用しても大きな差は生じ ないと考えたからである，その結果，\% $\mathrm{HR}_{30}$ もVT 水準以下の運動ではほほ一定の值を示し, しかも $\mathrm{T}_{30}$ との間にも強い相関関係が認められ た.したがって，\% $\Delta \mathrm{HR}_{30}$ は運動終了後におけ る副交感神経の再興樌過程の指標として妥当であ ク，また，フィールドで普通に用いられている心 拍数記録器を用いれば, 測定誤差は大きくなると しても，簡便に求めることができるので， $T_{30}$ よりさらに有用な指標であろうと思われる.

Imai たち ${ }^{1)}$ は, よく鍛錬されたクロスカント リースキー選手の $\mathrm{T}_{30}$ は, 一般健常者よりも有 意に短縮していることを示した。本研究では, ト レーニング水準の様々な対象者において， $\mathrm{T}_{30}$ および \% $\Delta \mathrm{HR}_{30}$ と体力水準との関連性を検討し たところ,どちらの指標でも $\mathrm{VO}_{2} \max$ との間に 有意の相関関係が認められた. Imai たちと我々 の成績から, 体力水準の高い者では運動終了後の 副交感神経の再興奮過程が方進していることが示 唆され，また，簡便な指標である $\% \Delta \mathrm{HR}_{30} に も$ 体力水準が反映されることが示された。

高い競技レベルのアスリートは，高度な技術や 体力水準が要求されるため, 常に生理的および心 理的限界に近い状況でトレーニングを行わなけれ ばならない.そのために，トレーニングと回復の バランスを崩し, 疲労の蓄積によるコンディショ ンの低下を生じやすい. さらに，このような状況 下で過度なトレーニングが継続されると，オー バートレーニング症候群と呼ばれる病的疲労状態 に陥る恐れもある。オーバートレーニング症候群 では，正常な状態に比して，睡眠中や起床時の心 拍数が増大したり ${ }^{3)}$, 最大下運動負荷時の心拍数 や血中乳酸濃度などが増大することが報告されて いる7)。また, 高田たち ${ }^{8)}$ は過酷な急性負荷 (超 長距離走レース) 後の睡眠時心拍変動の変化を検 討し, 交感神経緊張の回復遷延と副交感神経緊張 の充進が生じた可能性を示唆している.したがっ て,オーバートレーニング症候群や過労状態では, 自律神経系や内分泌系の機能異常が生じている可
能性が大きい。このような機能異常が, 運動負荷 後における副交感神経の再興奮過程にも反映され れば，上述したように簡便に求めることができる 指標で評価できるので，アスリートのコンディ ショニングにとって意義が深いと思われる.

本研究において, 大学陸上中長距離走選手の 夏季強化合宿中の毎朝のトレーニング前に $\% \Delta \mathrm{HR}_{30}$ を測定した．前日のトレーニングスケ ジュールがほほ同じであった合宿前半と後半の 6 日間ずつを選び，\% $\Delta \mathrm{HR}_{30}$ の平均值を比較した が，両者の間に有意差は認められなかった。被験 者は日頃からよくトレーニングを積んでいるアス リートであり，合宿期間中に体力水準が有意に変 化する可能性は少ないのであろう。一方, 毎日の $\% \Delta \mathrm{HR}_{30}$ の変動を観察すると，\% $\mathrm{HR}_{30}$ は前日 の走行距離と連動する変化を示した。すなわち, 前日のトレーニング量が多かった朝には \% $\mathrm{HR}_{30}$ が低值を示し, 前日のトレーニング量が少 なく疲労が回復していると思われる朝には高值を 示した. アスリートの体力水準がトレーニング負 荷に合わせて毎日変動する可能性は少ないであろ うから, \% $\mathrm{HR}_{30}$ の変動はトレーニング内容に 伴う疲労等の生体の反応の変化によるものと考え る方が妥当であろうと思われる。ただし，合宿期 間中に強い疲労感を訴えた者やオーバートレーニ ング症候群のような病的疲労状態を示す者はいな かったので, トレーニング量が多い日の翌朝の $\% \Delta \mathrm{HR}_{30}$ の低值を疲労による低下とするより， トレーニング量の少ない日の翌朝の $\% \Delta \mathrm{HR}_{30}$ の 高値を休養による副交感神経機能の充進と考える ほうが妥当であるという可能性もある.

アスリートのコンディショニングのための指標 が意味のある指標であるためには, 生理的な意味 が明確な指標と対比して妥当性が保証されること が重要であるが，フィールドで簡便に求めること ができる指標であることも重要である．本研究で 提案した $\% \Delta \mathrm{HR}_{30}$ は, 運動終了後の副交感神経 の再興奮過程を反映するとされる $\mathrm{T}_{30}$ と強い相 関関係にあった. $\% \Delta \mathrm{HR}_{30}$ および $\mathrm{T}_{30}$ の測定に は皦密な運動負荷強度の設定が不要であり, 特に $\% \Delta \mathrm{HR}_{30}$ はフィールドで簡便に求めることがで 
きるので，指標としての意義が大きい．\% $\mathrm{HR}_{30}$ は, 日常的に用いられている機器を装着して, ト レーニング前のウォームアップとして行われる ジョギング程度の負荷を数分間持続するだけで求 めることができる.

以上, $\% \Delta \mathrm{HR}_{30}$ と体力水準との間に関連がみ られたほか, 大学中長距離走選手の夏季強化合宿 において,トレーニングに伴う疲労等の生体反応, あるいはその回復状況と連動したことが示唆され る変動を示し，オーバートレーニング回避の一助 になる可能性が考えられた。本研究では，合宿中 における短期間の変動を被験者全体の平均值から のみ検討したが, 今後, 他のコンディショニング の指標とも関連させ長期的な観察を行い, 個人毎 の変動を検討すれば, 個人のコンディショニング について有用な情報が得られると思われる.

\section{V. 要䄪}

本研究では, $\% \Delta \mathrm{HR}_{30}$ が副交感神経の再興奮 過程の指標として $\mathrm{T}_{30}$ に代わりうるか否かを検 討するため, 強度の異なる定量運動負荷を加えて, 両者を比較した. $\mathrm{T}_{30}$ および $\% \Delta \mathrm{HR}_{30}$ は， $40 \%$ VT および $80 \%$ VT 強度の運動負荷において， それぞれほほ等しい值を示した。 $\mathrm{T}_{30}$ と\% $\mathrm{HR}_{30}$ との間には強い相関関係が認められた。さ らに，両者と $\mathrm{VO}_{2} \max$ との間にそれぞれ有意の 相関関係が認められた。 これらの成績から，\% $\mathrm{HR}_{30}$ は運動負荷終了後の副交感神経の再興奮過 程を反映する指標であることが示唆され，運動負 荷が VT 水準以下であれば厳密な強度の設定が 不要であること，また，体力水準も反映する指標 であることが示された. 次いで, $\% \Delta \mathrm{HR}_{30}$ がト レーニングに伴うアスリートの疲労等の生体反応 を反映するか否かを検討するため, 大学陸上部中
長距離走選手の夏季強化合宿において, 毎朝のト レーニング開始前に \% $\Delta \mathrm{HR}_{30}$ をフィールドテス トにより測定し，トレーニング状況と対応させて 検討したところ，\% $\Delta \mathrm{HR}_{30}$ はトレーニング量が 多かった日の翌朝には低值を，休養を主体にした 日の翌朝には高値を示した。すなわち，\% $\% \mathrm{HR}_{30}$ は疲労等の生体反応，あるいはその回復状況を反 映している可能性が示唆された。

（受理日 平成11年 5 月11日）

\section{参支献}

1) Imai K., Sato H., Hori M., Kusuoka H., Ozaki H., Yokoyama H., Takeda H., Inoue M., \& Kamada T. Vagally mediated heart rate recovery after exercise is accelerated in athletes but blunted in patients with chronic heart failure. J. Am. Coll. Cardiol., (1994), 24, 1529-1535.

2) Dressendorfer R. H., Wade C. E., \& Scaff J. H. Increased morning heart rate in runners : a valid sign of overtraining? Phys. Sportsmed., (1985), 13(8), 77-81.

3) Costill D. L. Inside Running, 1 st Ed., Chap. 5, Benchmark Press, Indianapolis, (1986), 123-134.

4) Beaver W. L., Wasserman K., \& Whipp B. J. A new method for detecting anaerobic threshold by gas exchange. J. Appl. Physol., (1986), 60, 2020-2027.

5) Edington E. S. Randomization tests, 3 rd Ed. Marcel Dekker, New York, (1995)

6） D. H. バーロー, M. ハーセン (高木俊一郎, 佐久間 徹監訳)，一事例の実験デザインーケーススタディ の基本と応用一, 改版, 第 9 章, 二瓶社, 東京, (1997), 195-222.

7) Kuipers H., Verstappen F. T. J., Keizer H. A., Geurten P., \& VanKranenburg G. Variability of aerobic performance in the laboratory and its physiologic correlates. Int. J. Sports Med. (1985), 6, 197-201.

8) Takada H., Musya H., Nagashima J., Murayama M., Sugai J., Watanabe M., Ariyoshi M., Kawahara T. \& Amemiya $T$. Response of cardiac autonomic nervous system in fatigue after super marathon. Jpn. J. Phys. Fitness Sports Med. (1991), 40, 581. (abstr) 